\title{
Communication between the community and local government - Case the Municipality of Pristina
}

\author{
Ferdi Kamberi $^{1}$ \\ ${ }^{1}$ University of Prishtina \\ Rr. "George Bush", p. n., 10000 Prishtinë, Republika e Kosovës
}

DOI: $10.22178 /$ pos.58-6

\section{LCC Subject Category: HM756-781}

Received 25.03.2020

Accepted 25.05.2020

Published online 31.05.2020

Corresponding Author:

Ferdi Kamberi

ferdikamberi04@gmail.com

(C) 2020 The Author. This article

is licensed under a Creative

Commons Attribution 4.0 License

(c) (i)

\begin{abstract}
In recent years, the development of local government in the most developed countries has been oriented toward creating a new kind of partnership with the community, giving to the community an important role in policymaking and decision-making, something that is recommended by the European Charter of Local Government. Communication between the local government and the community through different communication channels/means, also in Kosovo, is an important alert or signal that the community to become an important part of public policies, although the participation of the communities in public meetings is still low, and the data derived from relevant local and international studies, also this study as well proves that the participation of the communities in drafting and developing the policies is very low. By seeing the role and importance of communication in the dialogue, cooperation, promotion and empowerment of an active community in local decision making, the goal and aim of this paper is to analyze the forms/ways of communication between the community and local government in the Pristina region, respectively in 5 municipalities: Pristina, Fushë Kosovë, Obiliq, Gllogoc dhe Gracanica, then the sources of information through which ones the community is being informed about various public meetings, also another aim is to make comparisons between the above-mentioned municipalities regarding the use of local mechanisms in decision-making.

The methodology used in this paper has focused on the analysis of various studies and reports on local government and community, as well as on quantitative research to measure community opinion in the municipalities of the Pristina region. The overall results of this paper emphasize that the community is mainly informed by the local government through social networks, the municipality's website, local TV, the announcement board in municipalities, and other sources. Whereas, the local decision-making mechanisms used so far by the community are: petitions, civic initiatives, consultative committees, public meetings, but no initiatives to remove/step out mayors, although in principle some communities in some municipalities are not satisfied with their work.
\end{abstract}

Keywords: community; communication; local government; decision making; democracy.

\section{INTRODUCTION}

Communication is a very important process that connects peoples, breaks down the cultural, ethnic, political, racial, gender, religious barriers/obstacles and strengthens the social bond, and have an impact in individuals or social groups to share information among them. And isn't by coincidence to be referred to as "key to the success", because, through the communica- tion, sublime values have been created which has an impact on the improvement of human living conditions. Communication between the local government and the community has a major role and importance, firstly in informing them about the work of the local government, because it is the citizens/community who, through their veto, have elected their representatives, and secondly, through informing the community, they will take their role in policymaking and decision making. 
The municipalities of the Pristina region, they use a variety of communication methods and channels with their communities, to involve them in important processes, among these methods and channels we can mention social media, which have shown to be a very effective way to inform and to cooperate with the communities. Such communication makes the community use local decision-making mechanisms, which enriches democracy and makes that the community to improve life and life quality. This piece of work treats the issues of the relations between the local government and the community, their communication, cooperation decision-making process, and involvement of the community in the local government policies in the municipalities of the Pristina region, which also are the main research questions.

The main hypothesis that we have raised are

H1: Communication ways of Pristina municipality that includes modern methods, by using social media, local TV stations, billboards, etc.

H2: Mechanisms of local decision making are democratic instruments that enhance community development and through them help the local democracy, local decision, and policymaking.

The analysis of the above-given hypothesis has been elaborated through primary, secondary, and tertiary data, shown in this paperwork.

\section{METHODOLOGY AND METHODS}

Among many methodologies used in the paperwork, we can mention some scientific methods such as the content analysis method, through which method we have analyzed and elaborated scientific theories on communication, community development, and local government. Statistical analysis has served to statistics for measuring the perception of the community about sources of information about public meetings in the municipalities in the Pristina region and to analyze the number of the local democratic mechanisms for participation and the involvement of the community.

The method of comparison has been a method through which we have compared the municipalities of Pristina region, among themselves related to the attendance in the public meetings, their sources of information, forms of communication between the community and the local government in above-mentioned municipalities as well the use of the local mechanisms of decision making on the municipalities in this region. Also, we have conducted quantitative research in the municipalities in the region of Pristina.

The research has been conducted by using the questionnaire and the direct technique with 550 respondents involved (Pristina 150 respondents, Fushe Kosove 100 respondents, Obilic 100 respondents, Gllogoc 100 respondents, and Gracanica 100 respondents). The sample was simple random one and combined so-called stratified by age (18 and above), gender ( $60 \%$ men and $40 \%$ women), and other data mostly biographic. The research was conducted throughout the years 2018 and 2019 and is part of my academic Ph.D. study. The error margin can be around $+/-3$. The questionnaire was semi-structured and had 24 questions, not including the biographical questions, and questions are mostly the closed type questions and filtered questions.

All the data we derived from the research are analyzed carefully and were processed through the program SPSS Nr. 24 and the same are used for this study.

\section{Literature review}

Communication in other words means dialogue, sharing information from the sender to the receiver and versa and as such, it is supposed to be old at least about 80.000 years. The meaning of the word communication comes from the Latin language "communicate" that means "to share", that helped humans to have a "cognitive map" on new information. Communication had a key role in the process of development of changes in history. Moreover, during the last century, it was the communication and information flow that influenced so-called mass mobilization which leads to the fall of the famous Berlin Wall that is considered as "globalizations birthday". In other words, communication has been the very need of the society to communicate and to break down the obstacles/barriers which have often been manifested conceptual, ideological, political, ethnical, racial, gender, religious, and other differences and through communication approaches all these differentiations are reduced.

Today, communication has evolved significantly, and there exist special fields that deal with this question. The scholars that study communication "analyze the development of communication skills in humans and theorize about how com- 
munication can be made more effective. It is the exchange of meaningful information between two or more people Communicative competence designates the capability to install intersubjective interactions, which means that communication is an inherently social interaction" [21]. In the social context, communication is a social interaction between two and more people involved, it is a part of one's identity and also a need to create social cohesion with others.

According to Niklas Luhmann [16] "communication is a synthesis or unity which results from three possible choices: information, message, and meaning. Each of these components is itself a contingent event". The development of science, technology, and computing has helped the significant advancement of communication and also on geographical distances, once incomprehensible and now they are not such. Moreover, virtual communication has led local government/authorities to develop online communication ways to communicate with the community, to measure the public opinion to their credibility, and to provide online services to the community for effective communication and receiving feedback from the community.

The well-known psychologist Maslow is right when he stresses the hierarchy of needs, according to him these needs are: physiological needs, the need for security, need for love and social belonging, need for respect, and need for selfactualization. Also, "humans have always sought to find a way to minimize or diminish geographical distances/barriers to communicate with the rest of the world and to explore other cultures". So we can emphasize that the purpose of communication is to exchange information between people, present work in this case to local authorities before the community, change behaviors and receive information, etc., these elements that develop the individual, community, and society, reduce prejudice and stereotypes, and create a better society. When talking about communication, we must bear in mind that the communication involves the exchange of thoughts and feelings, and besides just conveying a message, it can be understood as participation in the community" [9].

So, we can emphasize that the purpose of communication is to exchange information between parties, in our case, presentation of the performance of the municipality to the community, to change the behaviors and gather information and other elements that develop the individual, the community and society, to reduce prejudices and stereotypes and the main aim to create a better society.

\section{RESULTS AND DISCUSSION}

The development of modern societies has given the local government a different perspective from the past, thus transforming from an older stage to a new one. In this context, the political, administrative, and financial reforms that have been carried out through the decentralization processes in European countries over the last century, have proved to be effective, although with some significant problems/issues. One issue that has turned out to be positive in this segment has been the communication between local government on the one hand and the community on the other, making it possible for the community to become part of decision-making and policymaking. For this purpose, considering the role and relationship between local authorities and the community, we have analyzed scientific theories that are related to them.

The first theory that we have included in this elaboration is Communicative Action - This theory, presented by Habermas [4], builds on what Habermas calls "communicative rationality". So communicative action is based on a rational agreement reached through dialogue. In Habermas's theory, communicative rationality has the potential to create a society that is modern in the sense of being more open, accepting dialogue, and open to criticism. Habermas says we call someone rational if he makes it known his purpose, reveals his desire or purpose, expresses his feelings or his spiritual mood" [19]. Habermas's theory of communicative action fundamentally rests on a distinction between two concepts of rationality that shape knowledge to guide action 4. First, cognitive-instrumental rationality conducts action that alms at the successful realization of privately defined goals. These action types are either instrumental when they are directed at efficient interventions in a state of affairs in the world (e.g. through labor), or strategic, when they guide attempts to successfully influence the decisions of other actors (e.g. in relations of domination).

Second, communicative rationality underlies action that is aimed at mutual understanding, conceived as a process of reaching an agreement be- 
tween speaking subjects to harmonize their interpretations of the world" [4]. In this regard, Habermas points out that "local policies are also influenced by federal and state laws, national party policies and regulations. Although the system is located in one line, it is a self-producing system. Power and markets can be relatively detached from community, family, and group values.

At the same time, there is also the world of daily life or lifeworld that Habermas sees it is a product of language and culture". Lifeworld concept, according to Habermas "is about the everyday life that we share with others; it is the name by which the informal domains are named after, and the domains that do not carry out any political value, or any monetary market value, but are of social importance only. Some parts of these domains are family, political life outside of organized parties, culture, voluntary organizations, mass media, and others. Lifeworlds are also open to changes and revisions, which occurs gradually. Such changes and repairs to lifeworlds occur through communications and the discourse" [15].

Theory of Communitarianism - is the theory that has its roots in ancient Greek philosophy, though it has gone through important stages and processes, and today we can say that it is both a political program and a way of life. Communitarianism is seen and understood as a social philosophy that focuses on the common benefit (community) and different from other theories especially is different from the theory of liberalism which is individual-cantered. Amitai Etzioni in his book The Spirit of Community, on communitarianism, states that "We are a social movement to extend the moral, social and political environment. Change of heart, the section of renewing social ties, part of public life reform" [5]. Dietor Nohlen claims that communitarianism is about a "gathering of notions of a current, identified in North America since the early 1980s in social science and political philosophy, which represents a political movement shaped by communitarian ideas" [11]. In other words, it can be said that communitarianism "is the aspiration for a social order in which individuals are united by shared values that inspire and maintain community bonds" [1].

The key pillars of communitarianism today can be: moral renewal of society, no presence of puritanism, care for law and order in society, not making the state a police state, saving the family, without violating women's rights, moral education in schools, forbidding to indoctrinate students, new opportunities in community life, without looking at each other hostilely, giving man as much social responsibility as possible, without limiting individual rights, enabling claims to individual success by the common goal, without forcing people to live in asceticism, altruism and self-sacrifice, the creation of a new moral, social, and public order built based on radically renewed communities without puritanism and" [12].

From the sociological point of view these theories, but also other theories, which cannot be summarized, reflect the broad dimension of communication between the local government and the community for the local government to involve them in decision-making and policymaking and the community on the side and to promote community participation through their participation and to make the work of local bodies effective, transparent and accountable.

\section{Relationship between the local government and the community - Case of Pristina regions municipalities}

Communication is one of the most important issues in the development of the community and the relationship between the community and the local government. It is supposed that the communication development occurs within the context of a democracy that is deliberative and participating. Public discourse is not only a simple talk or conversation, but it is considered essential for the development of local democracy.

In Kosovo, the system of local government is a level system, that is, the central and local level, where the basic units of local self-government are the municipalities, which have: a) selfcompetencies, b) delegated competencies and c) extended competencies.

Local self-government in Kosovo is in line with the spirit of the European Charter of Local SelfGovernment whose aim is "to meet the lack of common European standards for measuring and safeguarding the rights of local authorities, which are closest to the citizen and give them the opportunity of participating effectively in the making of decisions making for the general interest" [3] although Kosovo is not yet a signatory party. As we know, there are 9 (nine) municipalities included in the region of Pristina, but in our pa- 
perwork, we have included only 5 of them (Pristina, Fushe Kosove, Obilic, and Gllogovc) for study and analysis purposes.

The relationship between the local government and the community is regulated by the Law on Local Self Government articles: "4.3. Municipalities shall implement their policies and practices to promote coexistence and peace between their citizens and to create appropriate conditions enabling all communities to express, preserve, and develop their national, ethnic, cultural, religious, and linguistic identities. 4.4. All municipal authorities shall be answerable to the citizens of the Municipality in the forms set by law. 4.5. Citizens of the municipality shall have the right to participate in the activities of the municipality, as prescribed by law [14].

Local government is "providing an opportunity for citizens who can exercise influence and control over their local affairs and express their will through voting, as well as lobbying and advocating for local authorities. Especially when they are dissatisfied with government policies. Local government provides an opportunity for citizens who can exercise influence and control over their local affairs and express their will through voting, as well as lobbying and advocating before local authorities. Moreover when they are not satisfied with government policies. The local level of government is mainly responsible for implementing policies, as it is "seen" as "the most appropriate" for proper decisions regarding policymaking and also for being considered as the closest to the citizens issued and concerns and for possessing most accurate information for solving their existing concerns" [1].

So, we can assume that the local government as "a governing institution that exercises its authority in a specific area of the country...where the authority of local government derives from chooses base" [17], it is the authority that should involve the community in drafting public policies, so they (community) to be part of it and give they contribute to it. Whereas the community through its contribution given, makes influence in its development and by achieving such, they protect their rights and interests. And such a thing can be achieved only when there is proper communication through the mechanisms of local decision making and other channels of communication.

\section{Communication and involvement of the community in decision making}

The development of modern societies, globalization the development of information technology, and other segments of modern life have made local authorities develop more pro-active communication with the community. Indeed, the development of democracy itself has enabled such a thing, as Fareed Zakaria put it: "... democracy, despite its shortcomings, democracy represents the only and best hopes for people around the world" [22].

Whereas, the famous sociologist Giddens states that: "over the last three hundred years, globalization has been driven by two important influences: the economic expansion of western countries and the intensification of communication.

These two processes are closely interrelated with each other. The digital age has intensified the process of globalization and deepened it in people's personal life" [13]. Local government is the one that needs to communicate with the community and the community has to be part of public policies because, in the end, those public policies are in function and their best interest. For this purpose, the community develops as an integral part of a social organization, and if the local government fails to meet the demands and needs of the community, then a priori this can affect community development itself. To have a constructive relationship between the community and local government, the local government must communicate with the community through various forms. This communication includes information, direct communication with citizens, participation in municipal act-drafting processes, holding public meetings whether for budget or various capital projects, and developing a partnership between local government and the community.

Through such forms local government invests in community development, making them part of public policy and that the community is also a kind of "observer" of their work. Participation in public meetings and participation of the community participation is likely to happen when there is constructive communication between involved parties, including timely and accurate information. From a community development perspective, "participation takes place in an environment where the diversity of voices is heard to research or identify problems, test solutions, and change 
regulations when the community finds deficiencies.

Communities with strong democratic networks can also be seen as communicatively integrated. This kind of integration in itself includes communicative activities that connect people, networks, and institutions within a community" [18]. In practice, citizens find it difficult to engage in dialog/discourse in public debates with political leaders, as Habermas says, such happens because of other local problems/issues, and also because most of the media are owned by big corporates who are related to the government.

Exactly, this dominance that causes the community to be a passive participant or to not take part in the participation, although in the case of Kosovo, the local government it is obliged to hold public meetings with citizens/community at least twice per year.

In Kosovo, communication and information flow between the local government and the community is carried out by the criteria set by the Administrative Instruction (MAP) No 1/2015 on Public Institution's websites, Administrative Instruction No 06/2018 on Minimal Standards for Public Consolations, also Administrative Instruction No 04/2018 on Transparency in Municipalities, moreover this instruction states that "municipal authorities are obliged to be transparent and to make available to the public all documents, decisions, and activities within legal limitations of the right of access to public documents and to implement the mechanisms for involvement of citizens in decision making" [20].

According to him, citizens can take initiatives to propose acts that are of general interest and need. This article talks about the way of communication between the local government and the citizens, including also communication through social networks which are extremely used in Kosovo and that this form is seen as one of those forms that can be easily noticed by the citizens as part of the communication for them to attend these meetings organized by the local authorities.

The very same line of communication is used also for other kinds of consultative meetings important for the participation of the community. The guideline speaks also about access to the public documents, which is part of guaranteed citizens' rights, also speaks about the forms of participation of citizens in decision-making, such as plan- ning, discussion, making decisions, implementation and monitoring" [20], these are the forms which are part of public policies cycle. From the communications point of view, different ways can be used to invite citizens and the community to be part of municipal projects.

Exactly, communication as an important part of the relationship between the local government and the community has been a crucial part of our survey which we have conducted with the respondents (community) in the municipalities of our case study.

On the question: How often do you participate in the public meetings in your municipality, we have received a wide variety of answers, though the majority of the respondents said that they do not participate or they do participate in some of these public meetings (Figure 1).

Based on this diagram, we can see the respondents from the municipality of Pristina, about $20 \%$ of them answered that they do participate in the most of the public meetings, $13.3 \%$ of them said they participated in the half of them, $24.2 \%$ in some of them and $30.8 \%$ not at any of these meetings. Respondents from the municipality of Obilic in the same question answered like this: in most public meetings $10 \%$ of them, in half of the public meetings $20 \%$, in some of the meetings $21.2 \%$ and $16.3 \%$ at none of the public meetings.

The situation in the municipality of Fushe Kosove, looks much better when talking about participation in the public meetings, from all respondents from this municipality, $30 \%$ of them answered that they participated in the most of the meetings, $20 \%$ in most of the meetings, $21.2 \%$ in some of the meetings and $15.7 \%$ at none of the public meetings.

$20 \%$ of the respondents from the municipality of Gllogoc, answered they have participated in the most of the public meetings, $13.3 \%$ of them answered they participated in half of the public meetings, $19.2 \%$ in some of the public meetings and $17.9 \%$ at none of them.

And at the last but not the least municipality of Gracanica, there $20 \%$ of them answered that they participated in most of the meetings, $33.3 \%$ in half of the meetings, $14.1 \%$ in some of the meetings and $19.2 \%$ at none of the public meetings. 


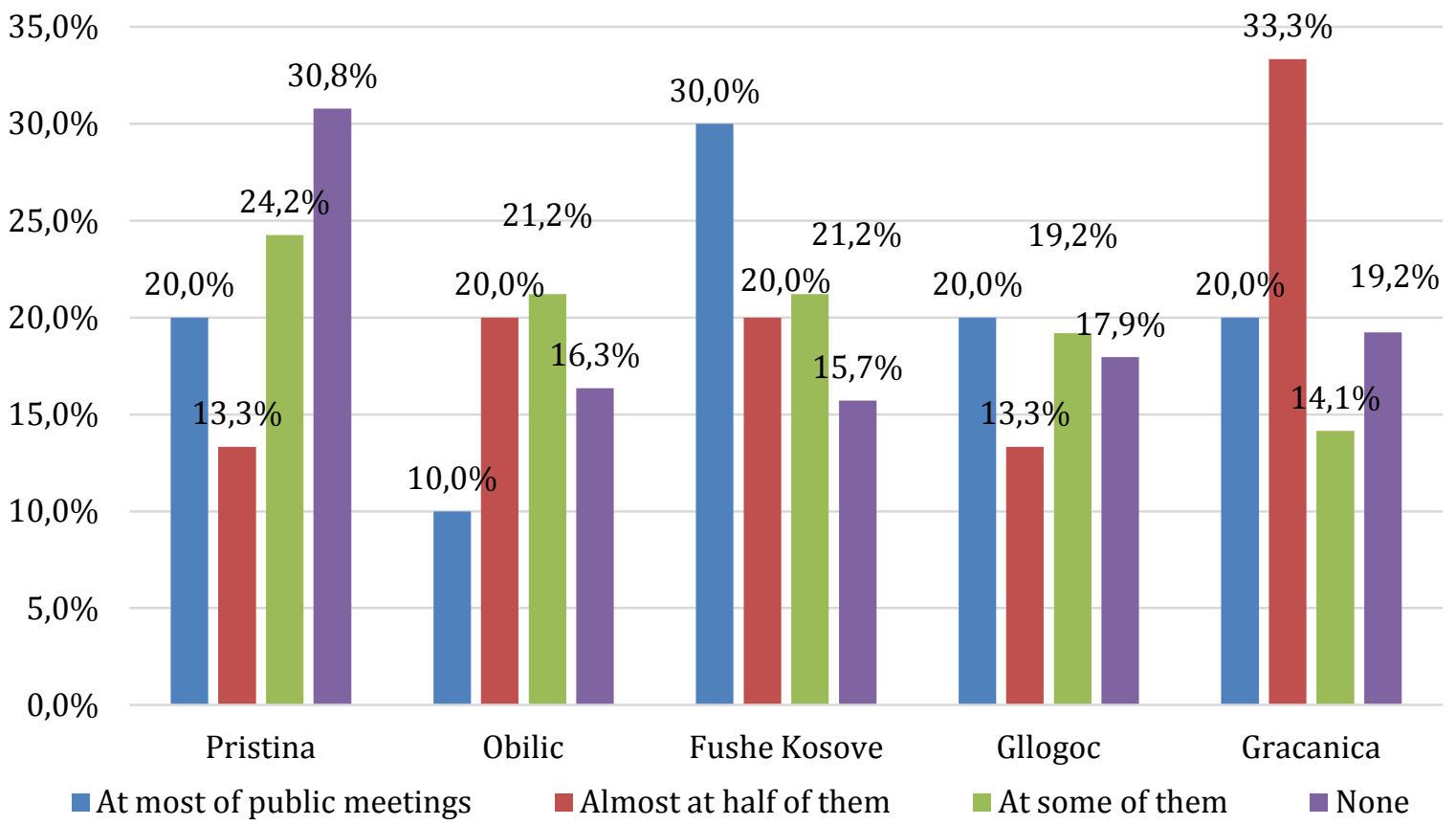

Figure 1 - Participation of the community from the municipalities of Pristina region in public meetings

(How often do you participate in the public meetings in your municipality?) [8]

Based on the data derived from this survey and presented above we can assume that if we make a comparison between the municipalities involved in this survey, we can see that the participation of the community in the public meetings which in other words means also the participation in the decision-making process, is low as a result of many factors such the dynamic of life and lack of time because the most of these public meetings are held during the daytime, while most of the citizens are at their workplaces or are busy with other activities, also another factor is that their opinion is not taken into consideration, lack of transportation, mainly in the rural areas, lack of information and other factors.

Maybe the most important factor among all is the lack of adequate information. Even though the local authorities do inform their citizens/community for such meetings, the informa- tion is being spread via municipality webpage, billboards, announcement boards, social and local media, etc. Such is in line with the analysis, researches, and other studies conducted by many different institutions in Kosovo.

According to a research conducted by the Institute GAP, in the municipality of Obilic, were 157 citizens from different locations, in the question: To what extend you are informed with the activities and work of your municipality? Only $10 \%$ of them answered that they are well informed, while $25 \%$ have declared that they are not well informed and $22 \%$ of them are not at all informed" [6], so these findings prove result from our study. In the other hand, when the citizens/community was asked about the sources of information about public meetings, they have mentioned social networks, not excluding other sources, see below (Table 1).

Table 1 - Local government sources for the community [8]

\begin{tabular}{|l|c|c|c|c|c|c|c|c|}
\hline Municipality & $\begin{array}{c}\text { Local } \\
\text { TV }\end{array}$ & $\begin{array}{c}\text { Municipality } \\
\text { webpage }\end{array}$ & $\begin{array}{c}\text { Announcement boards in } \\
\text { municipality }\end{array}$ & Billboards & Flyers & $\begin{array}{c}\text { Social } \\
\text { networks }\end{array}$ & Other & Total \\
\hline Pristina & 8.0 & 14.0 & 4.7 & 7.3 & 1.3 & 61.3 & 3.3 & 100.0 \\
\hline Obilic & 11.0 & 14.0 & 3.0 & 0.0 & 2.0 & 68.0 & 2.0 & 100.0 \\
\hline $\begin{array}{l}\text { Fushe } \\
\text { Kosove }\end{array}$ & 14.0 & 32.0 & 6.0 & 4.0 & 1.0 & 43.0 & 0.0 & 100.0 \\
\hline Gllogoc & 11.0 & 21.0 & 3.0 & 0.0 & 1.0 & 55.0 & 9.0 & 100.0 \\
\hline Gracanica & 19.0 & 16.0 & 14.0 & 8.0 & 10.0 & 33.0 & 0.0 & 100.0 \\
\hline
\end{tabular}

Notes: From what sources do you get more information about public meetings? 
Based on the Table 1, we can see the responses of the respondents from the municipality of Pristina, about $61.3 \%$ of them answered that they usually get information about public meetings from social networks, $14 \%$ of them from municipality webpage, $8 \%$ from local TV channels, $4.7 \%$ from announcement boards at the municipality, $7.3 \%$ from billboards, $1.3 \%$ from flyers and $3.3 \%$ from other sources.

At the Obilic municipality, about $68 \%$ they answered that they usually get information about public meetings from social networks, $14 \%$ of them from municipality webpage, $11 \%$ from local TV channels, $3 \%$ from announcement boards at the municipality, from billboards none, $2 \%$ from flyers and $2 \%$ from other sources.

It looks like the social networks are the main source of information for the community also to the other municipalities, so $43 \%$ of respondents from the municipality of Fushe Kosove have confirmed this, while $32 \%$ of them answered that the source of information for them is the municipality webpage, for $14 \%$ of them are local TV channels, for $6 \%$ announcement boards, $4 \%$ from billboards and only $1 \%$ from flyers.

We have noticed an increase in the percentage of respondents who use social networks at the municipality of Gllogoc in comparison with the municipality of Obilic, with $55 \%$ of respondents who have answered on this question, $21 \%$ of them got informed from municipality webpage, $11 \%$ from local TV channels, $3 \%$ from announcement board, $8 \%$ from billboards, $10 \%$ from flyers and $9 \%$ from other sources.

This comparison study does not exclude responses from the respondents from the municipality of Gracanica, who have a lower percentage of claims about being informed about public meetings by social networks. Thus, $33 \%$ of them claimed to be informed by social networks, which percentage is quite low compared to other municipalities in the region, then $19 \%$ of them claims to be informed by local TV channels, which number is a higher percentage than from other municipalities, $16 \%$ are informed by the municipal website, $14 \%$ by the municipal announcement boards, which is a higher percentage than the percentage of respondents from other municipalities, $8 \%$ from billboards and $10 \%$ of them from flyers.
These given data indicate that the community, in general, is more informed about public debates or such other meetings, to be informed by social networks more than other forms, although they are not excluded. In this context, such a thing has a sociological explanation. Taking into consideration the use of the internet (magic stick), namely, the very high number of internet users, most of them are informed about different events from social networks, and we know that these social networks can comment and share information with others.

Announcement boards in the municipality are another form of informing citizens about various notices/information, although this form mainly informs the community members who visit the municipalities to obtain various public services.

Local TV is mediums that have recently become more common in other municipalities and almost every municipality has a local media through which they can inform citizens.

The municipal website seems to be less visited as most of the information/news on the website is for the promotion of the mayor's activities rather than serving the citizens themselves. Therefore, this may also be one of the reasons why these websites are not being visited. However, another factor here is the fact that municipalities now have their websites and migration of relevant documentation and information takes a longer time, so some information is delayed, although the low number of public communication officers is also a factor, who are few but have high responsibilities and duties.

Another factor is the fact that social networks are more attractive than municipal websites and that Kosovo has a predominantly youth population, which means that they use mostly the internet when they are looking for information. Wellknown scholar Johan Gunther is probably right when he claimed that: "There are two groups: digital natives and digital immigrants. Digital natives are the people who have grown up with the internet and it is a gadget for them, an instrument no longer suspected. Digital immigrants are older people whose lives the Internet was created" [7]. Social networks as a form of communication were present also in the question below, where see what the respondents have stated (Figure 2). 
$\begin{array}{lllllll}0 & 20 & 40 & 60 & 80 & 100 & 120\end{array}$

Through participation in the public meetings

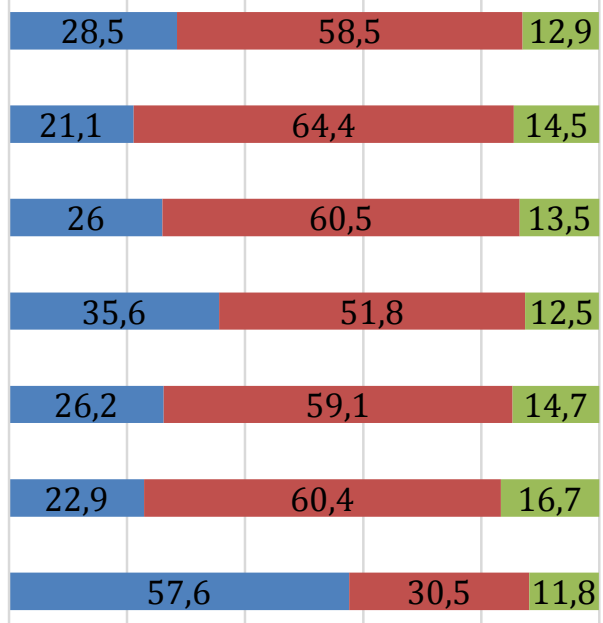

Communication through social networks

Through village councils

Through local communities

Meetings with municipal officials

Communication via emails

Communication through official letters

Yes $\quad$ No

Don't know/RF

Figure 2 - Communication of the community with the local government on issues of public interest (In what form do you communicate with the municipality on issues of public interest?) [8]

Communication, besides being a dialogue that includes sharing information between involved parties, which are usually the sender and the receiver. So the inter social relations are based on this. But, often during the communication process, unclarities and misunderstandings can occur, therefore, many institutions/organizations prefer more face to face communication, even though communication by emails can have a positive effect on reaching the goals.

So, about $26.2 \%$ of respondents stated that they communicate with the municipality (local government) via emails, $59.1 \%$ of respondents responded negatively and $14.7 \%$ refused to answer. Communication through official papers is less present, which is confirmed by the respondents. So, about $22.9 \%$ of them say they are communicating, $60.4 \%$ of them say they are not communicating at all and $16.7 \%$ refuse to answer or say they do not know.

This is evident as Kosovo has a high range of utilization of information technology in proportion to the number of inhabitants. Social networks are precisely a form of communication that is preferred also by most of the respondents of our research. So, about $57.6 \%$ of the respondents state that they prefer to communicate with local authorities via social networks, $30.5 \%$ of them don't communicate via social networks and $11.8 \%$ of them refuse to answer or say they do not know.

\section{Local democracy mechanisms and community in- volvement in decision making}

Local mechanisms of democracy are important tools for local governments used to involve or engage the community in policy and decision making. According to the Law on Local SelfGovernment, besides public meetings, which are very important for community participation in the process of decision making, there is some other decision-making mechanism such as civic initiatives, petitions, consultative committees, consultations and public hearings, referendums and other.

Involvement of the community within these mechanisms reveals an active citizenry and affects the development of local democracy or as Bauman puts it: "the ideal community is a complete Mappa Mundi: a total world, that supplies us with everything we need to have meaningful and rewarding life" [2], therefore, the participation of the community in these processes, gives inputs and enriches the local democracy, also influences to improve their lives.

During this study, we have analyzed the use of direct mechanisms for decision making by the community in the municipalities of Pristina region (Pristina, Fushe Kosove, Obilic, Gllogoc, and Gracanica) for the years 2017 and 2018, which are presented in the following table, see below (Table 2). 
Table 2 - The comparison between the municipalities of Pristina region regarding the use of mechanisms of direct democracy for year 2017/2018" [10]

\begin{tabular}{|l|c|c|c|c|c|}
\hline $\begin{array}{c}\text { Mechanisms of } \\
\text { participation in the } \\
\text { decision making } \\
2017 / 2018\end{array}$ & $\begin{array}{c}\text { Municipality of } \\
\text { Pristina }\end{array}$ & $\begin{array}{c}\text { Municipality of } \\
\text { Fushe Kosove }\end{array}$ & $\begin{array}{c}\text { Municipality of } \\
\text { Obilic }\end{array}$ & $\begin{array}{c}\text { Municipality of } \\
\text { Gllogoc }\end{array}$ & $\begin{array}{c}\text { Municipality of } \\
\text { Gracanica }\end{array}$ \\
\hline $\begin{array}{l}\text { Information and public } \\
\text { consultations }\end{array}$ & Yes & Yes & Yes & Yes & Yes \\
\hline Petitions & Yes & Yes & No & No & Yes \\
\hline Citizen's initiatives & Yes & No & Yes & No & No \\
\hline Referendum & No & No & No & No & No \\
\hline $\begin{array}{l}\text { Initiatives to remove the } \\
\text { mayors }\end{array}$ & No & No & No & No & No \\
\hline Consultative committees & Yes & Yes & Yes & Yes & Yes \\
\hline
\end{tabular}

If we look closely at the table above, Table 2, we can realize that the mechanisms of direct democracy when talking about the participation of the community in the decision making, the majority of them are applicable and used by the community for important causes and to improve the quality of life and their development.

Regarding information and public consultations, it is noticed that all 5 municipalities of the Pristina region use these mechanisms. The petition is just another important local mechanism, which was used by the municipality of Pristina, Fushe Kosove, and Gracanica in the years 2017 and 2018 , to regulate some infrastructural issues, regulating the urbanistic plans and other issues as they have reported.

While the municipality of Obilic and Gllogoc, according to them, they never used the petition as a mechanism. Citizen's initiatives as a form of direct democracy, we can see in the cases of the municipalities of Pristina and Obilic.

Here was used in the case of expropriation of land and for the mines in some of the villages of this municipality, while in the other three municipalities wasn't used at all. Although the referendums have not been yet regulated by law, we haven't noticed any initiative in this regard. Most notable, from this table, is the fact that that none of the municipalities had received any request to remove the mayors, although this is allowed and is possible according to the law on local government. Although the majority of the community, even during our research, they have expressed that they are not so satisfied with the performance of municipal authorities.

And finally, we have also so-called consultative committees, citizens participate and are part of them, and which, according to the declarations of municipal clerks, have been quite functional. In utilizing these important mechanisms for community participation in decision-making, civil society organizations, both local and international, have played an important role, making the community to be more self-initiative to use such mechanisms.

\section{CONCLUSION}

Based on what we have highlighted so far, we can conclude that the issue of communication as an important process in the development of dialogue between the parties involved is very important because, in addition to exchanging information, it also affects in eliminating different barriers, shortens the geographical distances and it also strengthens social cohesion in society.

The local government is obliged to communicate with the community and present their performance because it has received vetoes from the community itself.

Data from our studies, research, and our research has shown that in Kosovo local government communicates with the community through various forms defined by laws and regulations, including announcements for various public meetings, budget and public policy development locally, bulletin boards, local TV channels, social networks, the municipality's website, and other.

The development of science, technology, and informatics has made the internet extremely popular in Kosovo and as a result of this information and communication are now realized through social networks. 
On the one hand, this leads to more inclusive communication, on the other hand, social networks may not be as secure and may be hacked by other persons for misinformation.

What is also noticeable from the studies we have conducted is that despite some coverage, there is low community participation in decision-making, although there are several factors that have influenced this segment, including consideration of community opinions, life dynamics, lack of time, lack of timely information in more rural areas, and other factors. Also, as a conclusion of this paper, we have seen the use of local decisionmaking mechanisms, which in the municipalities of Prishtina region in 2017 and 2018 some of them have been used for the benefit of the community, thus proclaiming a local democracy.

In general, it can be said that there is a need for more adequate communication between the local government and the community, using other forms of communication, perhaps even visits neighborhoods or other settlements for the community to be near local government bodies and to have more active participation in policymaking and decision-making.

Local decision-making mechanisms should also be used to improve the quality of life and quality of the community and prove the test and maturity of both parties, both local government and the community itself, thereby strengthening the partnership between them.

\section{REFERENCES}

1. Baliqi, B. (2017). Public Policy and Governance. Prishtina: Foundation - Konrad Adenauer Stiftung.

2. Bauman, Z. (2017). Liquid Modernity. Tirana: Pika pa Siperfaqe.

3. Council of Europe. (2013). European Charter of Local Self-Government. Retrieved from https://rm.coe.int/16807198a3

4. Deflem, M. (2008). Law in Habermas's Theory of Communicative Action (El Derecho en la Teoría de la Acción Comunicativa de Habermas). Retrieved from https://www.researchgate.net/publication/241587004_Law_in_Habermas's_Theory_of_Commu nicative_Action_El_Derecho_en_la_Teoria_de_la_Accion_Comunicativa_de_Habermas

5. Etzioni, A. (2013). The Spirit of Community - Rights, Responsibilities, and the Communitarian Agenda. New York: Crown.

6. GAP Institute. (2018). The Gap between Institutions and Citizens in the Municipality of Kamenica. Retrieved from https://www.institutigap.org/documents/45763_municipality_kamenica(en).pdf

7. Gunther, J. (2008). Digital natives and digital immigrants. Innsbruck: Studien-Verl.

8. Kamberi, F. (2018). Community Development and Local Governance - Comparative Study of Municipalities of the Pristina region: results of pilot project.

9. Kamberi, F. (2019). The Dilemmas of Transition. Prishtina: Artini.

10. Kambery, F. (2018, November - December). Mechanism of the direct democracy in the municipalities of the Prishtina region [The notes are taken from respective municipalities' clerks]. Kosovo: n. d.

11. Kiçmari, S. (2004). Drejtpeshimi. Tiranë: Koçi

12. Kiçmari, S. (2008). The Idea, Purpose, and Practical Application of Communitarianism Theory. Social Studies, 2(2), 11.

13. Kunushevci, L. (2018). Contemporary Sociological Assemblies. Skopje: Logos-A.

14. Law on local self-government (Kosovo), 20.02.2008, No 03/L-040. Retrieved April 1, 2020, from https://mapl.rks-gov.net/wp-content/uploads/2017/10/Law-On-Local-Self-Government.pdf

15. Limani, H. (2013). Articulating African Philosophy: The Future Challenges of the Central Philosophy of Political Philosophy. Revista Njohja, 2(2), 137.

16. Luhmann, N. (2013). Theory of Society. Stanford: Stanford University Press. 
17. McLean, I., \& McLean, A. (2001). The Concise Oxford Dictionary of Politics. New York: Oxford University Press.

18. Phillips, R., Pittman, R. (2019). An Introduction to Community Development. New York: Routledge.

19. Sinanaj, A. (2019, December 16). The Culture of Telephony as 'Forgetting Being' - An Essay on the Problem of Technology from a Philosophical Perspective. Retrieved from https://www.mekulipress.com/kultura-e-telefonizimit-si-harrim-i-qenies-ese-mbi-problemine-teknologjise-sipas-kendveshtrimit-filozofik-heidegger-habermas

20. The Official Gazette of the Republic of Kosovo. (2020). Administrative instruction (MLGA No 04/2018). Retrieved from https://gzk.rks-gov.net/ActDetail.aspx?ActID=18373

21. Velentzas, J., Broni. G. (n .d.). Communication cycle: Definition, process, models and examples. Retrieved from https://pdfs.semanticscholar.org/da4e/69265653057d6f03fdc4ce3692b4e6923a0f.pdf?.ga=2. 120742987.2123808975.1591442676-1042230176.1581878685

22. Zakaria, F. (2007). The Future of Freedom - Illiberal Democracy at Home and Abroad. New York: W. W. Norton. 